ACTA THERIOLOGICA

Vol. 28, 10: 171-182, 1983

\title{
Chromosomes of Some Species of Vespertilionid Bats. II. Evolutionary Relationships of Plecotine Bats
}

\author{
Stanisław FEDYK \& Andrzej L. RUPRECHT
}

\begin{abstract}
Fedyk S. \& Ruprecht A. L., 1983: Chromosomes of some species of vespertilionid bats. II. Evolutionary relationships of plecotine bats. Acta theriol, 28, 10: 171-182 [With 2 Tables, 1 Fig. \& Plates VIII-IX] Differential staining revealed a total accordance of banding pattern for all the chromosomes of Plecotus auritus (Linnaeus, 1758) and Barbastella barbastellus (Schreber, 1774). The karyotypes of these two species are identical and consist of 32 chromosomes, including 10 pairs of metacentric autosomes, 5 pairs of telocentric autosomes, a submetacentric $\mathrm{X}$-chromosome, and a small acrocentric $\mathrm{Y}$-chromosome. In the description of banded karyotypes of $P$. auritus and $B$. barbastellus chromosome arms of Nearctic species are numbered from 1 to 25 , as proposed by Bickham. The mechanism of karyotype formation in different Plecotini forms is discussed, as compared with the Myotini karyotype and the ancestral karyotype of the earliest Vespertilionidae $(2 \mathrm{~N}=50 ; \mathrm{NFa}=48)$.

[Mammals Res. Inst., Polish Acad. Sci., 17-230 Białowieża, Poland]
\end{abstract}

\section{INTRODUCTION}

The term "Plecotini group" as an equivalent to a subfamily was introduced by Dobson (1863, in Handley, 1959). Dobson used it for a few genera of Vespertilionidae characterized by unusually long ears (Plecotus, together with American forms such as Corynorhinus and Idionycteris, Euderma, Histiotus, Laephotis, Otonycteris, Nyctophilus, Pharotis, Antrozous). Miller (1897, in Handley, 1959) used the term Plecotinae (as a subfamily) for American forms of Plecotus and Euderma. Later, however, Miller (1907) discarded the term Plecotinae and included bigeared bats in the family Vespertilionidae. The classification developed by Dobson (l.c.) and the original classification used by Miller (1897) were based on the structure of the auditory apparatus only and, as Handley (1959) noticed, these characters do not necessarily reflect relationships between genera. Tate (1942) used other characters, which can better reflect phylogenetic associations. He proposed that the forms of Plecotus, Corynorhinus, Idionycteris, and Euderma be included in Myotini, as descendants of the Myotis stock with a differentiated degree of evolution. H. Allen (1864, in Handley, 1959) recorded some similarities between Plecotus and Barbastella, introducing a common name Synotus for these two forms. 
Handley (1959) basically accepted the classification developed by Tate (1942) and grouped the genus Plecotus in three subgenera: group Myotini - genera Euderma, Plecotus - subgenera Idionycteris, Plecotus, Corynorhinus.

Handley (1959) in his comprehensive morphological analysis concluded that Idionycteris is the basal or relict form, while Plecotus and Corynorhinus represent later stages of evolution. Williams et al. (1970), who studied the chromosomes of American forms (Euderma and Plecotus), suggested removing big-eared bats from Myotini and forming a group Plecotini, consisting of such genera as Barbastella, Euderma, Idionycteris, and Plecotus with subgenera Plecotus and Corynorhinus. These authors presented their views on the phyletic relationships between these forms. Very similar conclusions concerning Plecotus, Corynorhinus, and Idionycteris were reached by Fedyk \& Fedyk (1971), who studied European forms of Plecotus.

The position of the genus Barbastella is not so clear. Miller (1907) stated that despite great differences in the dental pattern, development of the auditory capsule, and zygomatic arch, Barbastella is more similar to Plecotus and Euderma than to any other genus. Tate (1942), however, suggested that the genera Plecotus and Euderma descended from the Myotis stock (Myotini sensu lato), while Barbastella is a representative of Pipistrellini. This view was questioned by Handley (1959), who argued that the similarity between Barbastella and Pipistrellus is of secondary character. He emphasizes, like Miller (1907), the similarity to Plecotus and Euderma, considering the genus Barbastella as a group Plecotini with non-specialized auditory apparatus. The analysis of chromosomes by conventional methods (Capanna et al., 1968; Williams et al., 1970) suggested that Handley (1959) was right.

The chromosomes of the Eurasian genera Barbastella and Plecotus were frequently described (Bovey, 1949; Capanna et al., 1968; Fedyk \& Fedyk, 1970, 1971; Uchida \& Ando, 1972; Harada, 1973; Baker et al., 1974; Ando, 1977; Zima, 1978; Tsuchiya, 1979). The chromosomes of Nearctic forms (Euderma, Plecotus and Idionycteris) were described by Baker \& Patton (1967), Baker \& Mascarello (1969), Williams et al. (1970), and Bickham (1979a). A detailed analysis of the American material based on the G-banding pattern is given by Bickham (1979a), together with conclusions on phylogenesis. The present study supplements this analysis with European species. 


\section{MATERIAL AND METHODS}

The material for the analysis consisted of one male $P$. auritus captured at Kowal, Włocławek district, and two male B. barbastellus caught in Białowieża, Bialystok district, in 1981 and 1982.

Chromosome preparation of the bone marrow and spleen were made. Colcemid was intraperitoneally injected in a dose of $0.002 \mathrm{mg}$ per $1 \mathrm{~g}$ of body weight for $0.5 \mathrm{~h}$. Hypotonization was carried out in $0.075 \mathrm{M}$ solution of $\mathrm{KCl}$ at room temperature for 30 minutes. Air-dried preparations after a period of 4-6 days were digested with trypsin and stained with Giemsa solution using the Seabright (1971) method.

For the description of banded karyotypes of $P$. auritus and B. barbastellus, chromosome arms of Nearctic species were numbered from 1 to 25 , according to Bickham $(1979 \mathrm{a}, \mathrm{b})$. Banding patterns were compared with those of telocentric chromosomes of Eptesicus serotinus. It has been found (Fedyk \& Ruprecht, 1983), that the banding pattern in E. serotinus is identical with that in Eptesicus fuscus (Bickham, 1979a).

\section{RESULTS}

The karyotypes of $P$. auritus and B. barbastellus were identical and consisted of 32 chromosomes: 10 pairs of metacentric autosomes, 5 pairs of telocentric autosomes, a submetacentric $X$-chromosome, and a small acrocentric Y-chromosome (Plate VIII).

The differential staining indicated that the banding patterns of all $P$. auritus and $B$. barbastellus chromosomes are exactly alike. According to the terminology used by Bickham $(1979 a, b)$, the arm combinations in metacentric autosomes of $P$. auritus and $B$. barbastellus were as follows: $1 / 2,3 / 4,5 / 6,12 / 10,13 / 9,15 / 11,22 / 8,21 / 7,19 / 14$, and 16/17. The telocentric autosomes, because of their small size, had less clear-cut banding but were still comparable with the corresponding autosomes of Eptesicus and were numbered 18, 20, 23, 24, and 25. The X-chromosomes had a relatively weakly expressed banding pattern: on the short arm there occurred one conspicuous band located more or less in the medial part of this arm, while the long arm had one dark-stained block. The distal end of this arm remained unstained, while a very intense dark band was located at the centromere. On some metaphasal plates this last band was separated from a large block of dark bands by a narrow, light band. The $Y$-chromosome lacked clear-cut banding (Plate IX).

\section{DISCUSSION}

There is a relatively large body of literature on the chromosomes of big-eared bats. The first information on the chromosomes of $P$. auritus and B. barbastellus was given by Bovey (1949), who found that each of 
these two species collected in Switzerland had 32 chromosomes. A more detailed analysis, with the application of colchicine, confirmed Bovey's findings for P. auritus collected in Poland (Fedyk \& Fedyk, 1970, 1971) and Czechoslovakia (Zima, 1978), and for an Asiatic subspecies, P. auritus sacrimontis (Harada, 1973; Ando et al., 1977; Tsuchiya, 1979). Ten pairs of metacentric autosomes were recorded, i.e., $\mathrm{NFa}=50$. An identical chromosome pattern was described for Plecotus austriacus (Fedyk \& Fedyk, 1970, 1971; Baker et al., 1974; Zima, 1978). Zima (1978) recorded 52 autosome arms for the two European Plecotus species, because he included with the metacentric chromosomes also one of the smallest pairs of autosomes. An analysis of the measurements of the chromosomes of $P$. auritus and $P$. austriacus showed some differences in the position of the centromeres of three autosome pairs and the $X$-chromosome (Fedyk \& Fedyk, 1971). In the light of these results, it is certainly interesting to compare the banding patterns in these two species.

More recent studies of the chromosomes of $B$. barbastellus captured in Italy (Capanna et al., 1968) confirmed the findings of Bovey (1949): $2 \mathrm{~N}=32 ; \mathrm{NFa}=50$. The same karyotype was found in an Asiatic species, Barbastella leucomelas (Uchida \& Ando, 1972; Ando et al., 1977). Only Zima (1978) recorded 52 autosome arms at $2 \mathrm{~N}=32$ for $B$. barbastellus as in Plecotus species caught in Czechoslovakia.

In all the cases described above, when $\mathrm{NFa}$ was greater than 50 , an additional metacentric autosome of very small size was recorded, thus there is some doubt whether these are in fact metacentric chromosomes and, if so, whether they have been overlooked in the other cases. Ignoring these puzzling discrepancies, it should be stated that all Palaearctic species of Plecotus and Barbastella have uniform karyotypes (Table 1).

The chromosomes of three species of Nearctic Plecotus (subgenus Corynorhinus) were studied. These were Plecotus townsendii and P. rafinesquii, in which there were 32 chromosomes and 50 autosome arms (Baker \& Patton, 1967; Baker \& Mascarello, 1969; Williams et al., 1970; Anthony \& Kitchin, 1976; Bickham, 1979a), and also Plecotus (Idionycteris) phyllotis with 30 chromosomes and 50 autosome arms (Baker \& Patton, 1967; Baker \& Mascarello, 1969; Williams et al., 1970; Bickham, 1979a).

The $\mathrm{X}$-chromosomes are also differentiated in Nearctic Plecotus (Idionycteris) phyllotis. The X-chromosome is submetacentric, as in the Eurasian species of Plecotus and Barbastella, while in Plecotus (Corynorhinus) townsendii and $P$. (C.) rafinesquii it is acrocentric (Table 1 ).

In Euderma maculatum, 30 chromosomes were recorded and $\mathrm{NFa}=52$ 
(Williams et al., 1970). It was suggested that the karyotype of Euderma was closest to that of $P$. (Idionycteris) phyllotis, though also distinct morphological differences between these two species (Williams et al.,

Table 1

Chromosome patterns in big-eared bats. Morphology of sex-chromosomes: a acrocentric, sm - submetacentric, $\mathrm{m}$ - metacentric.

\begin{tabular}{|c|c|c|c|c|c|c|c|}
\hline \multirow[t]{2}{*}{ Species } & \multirow[t]{2}{*}{$2 \mathrm{~N}$} & \multirow{2}{*}{$\mathrm{NFa}$} & \multicolumn{2}{|c|}{$\begin{array}{c}\text { No. of } \\
\text { autosome } \\
\text { pairs }\end{array}$} & \multirow{2}{*}{\multicolumn{2}{|c|}{$\begin{array}{l}\text { Morphology } \\
\text { of sex- } \\
\text { chromosomes } \\
\text { X Y Y }\end{array}$}} & \multirow[t]{2}{*}{ References } \\
\hline & & & $\begin{array}{l}\text { bi- } \\
\text { rmed }\end{array}$ & $\begin{array}{l}\text { uni- } \\
\text { armed }\end{array}$ & & & \\
\hline $\begin{array}{l}\text { Euderma } \\
\text { maculatum }\end{array}$ & 30 & 52 & 12 & 2 & $\mathrm{sm}$ & a & Williams et al., 1970 \\
\hline \multirow{4}{*}{$\begin{array}{l}\text { Plecotus } \\
\text { (Idionycteris) } \\
\text { phyllotis }\end{array}$} & 30 & 50 & 11 & 3 & $?$ & $?$ & Baker \& Patton, 1967 \\
\hline & 30 & 50 & 11 & 3 & sm & a & $\begin{array}{l}\text { Baker \& Mascarello, } \\
1969\end{array}$ \\
\hline & 30 & 50 & 11 & 3 & $\mathrm{sm}$ & a & Williams et al., 1970 \\
\hline & 30 & 50 & 11 & 3 & sm & a & Bickham, 1979a \\
\hline \multirow{5}{*}{$\begin{array}{l}\text { Plecotus } \\
\text { (Corynorhinus) } \\
\text { townsendii }\end{array}$} & 32 & 50 & 10 & 5 & $?$ & $?$ & Baker \& Patton, 1967 \\
\hline & 32 & 50 & 10 & 5 & a & a & $\begin{array}{l}\text { Baker \& Mascarello, } \\
1969\end{array}$ \\
\hline & 32 & 50 & 10 & 5 & a & a & Williams et al., 1970 \\
\hline & 32 & 50 & 10 & 5 & a & a & $\begin{array}{l}\text { Anthony \& Kitchin, } \\
1976\end{array}$ \\
\hline & 32 & 50 & 10 & 5 & a & a & Bickham, 1979a \\
\hline $\begin{array}{l}\text { Plecotus } \\
\text { (Corynorhinus) } \\
\text { rafinesquii }\end{array}$ & 32 & 50 & 10 & 5 & a & a & $\begin{array}{l}\text { Baker \& Mascarello, } \\
1969\end{array}$ \\
\hline \multirow{2}{*}{$\begin{array}{l}\text { Plecotus } \\
\text { (Plecotus) } \\
\text { austriacus }\end{array}$} & 32 & 50 & 10 & 5 & $\operatorname{sm}$ & a & $\begin{array}{l}\text { Fedyk \& Fedyk, 1970; } \\
1971\end{array}$ \\
\hline & $\begin{array}{l}32 \\
32\end{array}$ & $\begin{array}{l}50 \\
50\end{array}$ & $\begin{array}{l}10 \\
10\end{array}$ & $\begin{array}{l}5 \\
5\end{array}$ & $\begin{array}{r}\mathrm{m} \\
\mathrm{sm}\end{array}$ & $\begin{array}{l}\mathrm{a} \\
\mathrm{a}\end{array}$ & $\begin{array}{l}\text { Baker et al., } 1974 \\
\text { Zima, } 1978\end{array}$ \\
\hline \multirow{4}{*}{$\begin{array}{l}\text { Plecotus } \\
\text { (Plecotus) auritus }\end{array}$} & 32 & 50 & 10 & 5 & $\mathrm{~m}$ & a & Bovey, 1949 \\
\hline & 32 & 50 & 10 & 5 & $\mathrm{sm}$ & a & $\begin{array}{l}\text { Fedyk \& Fedyk, 1970; } \\
1971\end{array}$ \\
\hline & 32 & 54 & 12 & 3 & sm & a & Ando et al., 1977 \\
\hline & $\begin{array}{l}32 \\
32\end{array}$ & $\begin{array}{l}50 \\
50\end{array}$ & $\begin{array}{l}10 \\
10\end{array}$ & $\begin{array}{l}5 \\
5\end{array}$ & $\begin{array}{l}\mathrm{sm} \\
\mathrm{sm}\end{array}$ & $\begin{array}{l}\mathrm{a} \\
\mathrm{a}\end{array}$ & $\begin{array}{l}\text { Zima, } 1978 \\
\text { This paper }\end{array}$ \\
\hline Plecotus auritus & 32 & 50 & 10 & 5 & $\mathrm{sm}$ & a & Harada, 1973 \\
\hline sacrimontis & 32 & 50 & 10 & 5 & $\operatorname{sm}$ & a & Tsuchiya, 1979 \\
\hline \multirow{3}{*}{$\begin{array}{l}\text { Barbastella } \\
\text { barbastellus }\end{array}$} & 32 & 50 & 10 & 5 & $\mathrm{sm}$ & a & Bovey, 1949 \\
\hline & $\begin{array}{l}32 \\
32\end{array}$ & 50 & 10 & $\begin{array}{l}5 \\
4\end{array}$ & $\begin{array}{l}\mathrm{sm} \\
\mathrm{sm}\end{array}$ & $\begin{array}{l}\mathrm{a} \\
\mathrm{a}\end{array}$ & Capanna et al., 1968 \\
\hline & $\begin{array}{l}32 \\
32\end{array}$ & $\begin{array}{l}52 \\
50\end{array}$ & $\begin{array}{l}11 \\
10\end{array}$ & $\begin{array}{l}4 \\
5\end{array}$ & $\mathrm{sm}$ & a & $\begin{array}{l}\text { Zima, } 1978 \\
\text { This paper }\end{array}$ \\
\hline $\begin{array}{l}\text { Barbastella } \\
\text { leucomelas }\end{array}$ & 32 & 50 & 10 & 5 & $\mathrm{sm}$ & a & Ando et al., 1977 \\
\hline $\begin{array}{l}\text { B. leucomelas } \\
\text { darjelingensis }\end{array}$ & 32 & 50 & 10 & 5 & $\mathrm{sm}$ & a & Uchida \& Ando, 1972 \\
\hline
\end{tabular}

1970) were recorded. The problem will not be solved until the banding pattern has been compared, but so far this has not been described for Euderma.

Anthony \& Kitchin (1976) and Bickham (1979a) described G bands in 
Plecotus (Corynorhinus) townsendii and Bickham (1979a) described them in Plecotus (Indionycteris) phyllotis. Together with the material used in the present work, we have data on banding patterns in four species of big-eared bats (Table 2). Bickham (1979a) stated that four pairs of metacentric autosomes $(1 / 2,3 / 4,5 / 6$, and $16 / 17)$ are totally homologous to the four pairs of metacentrics occurring in the karyotypes of various species of Myotis (Bickham, 1979b).

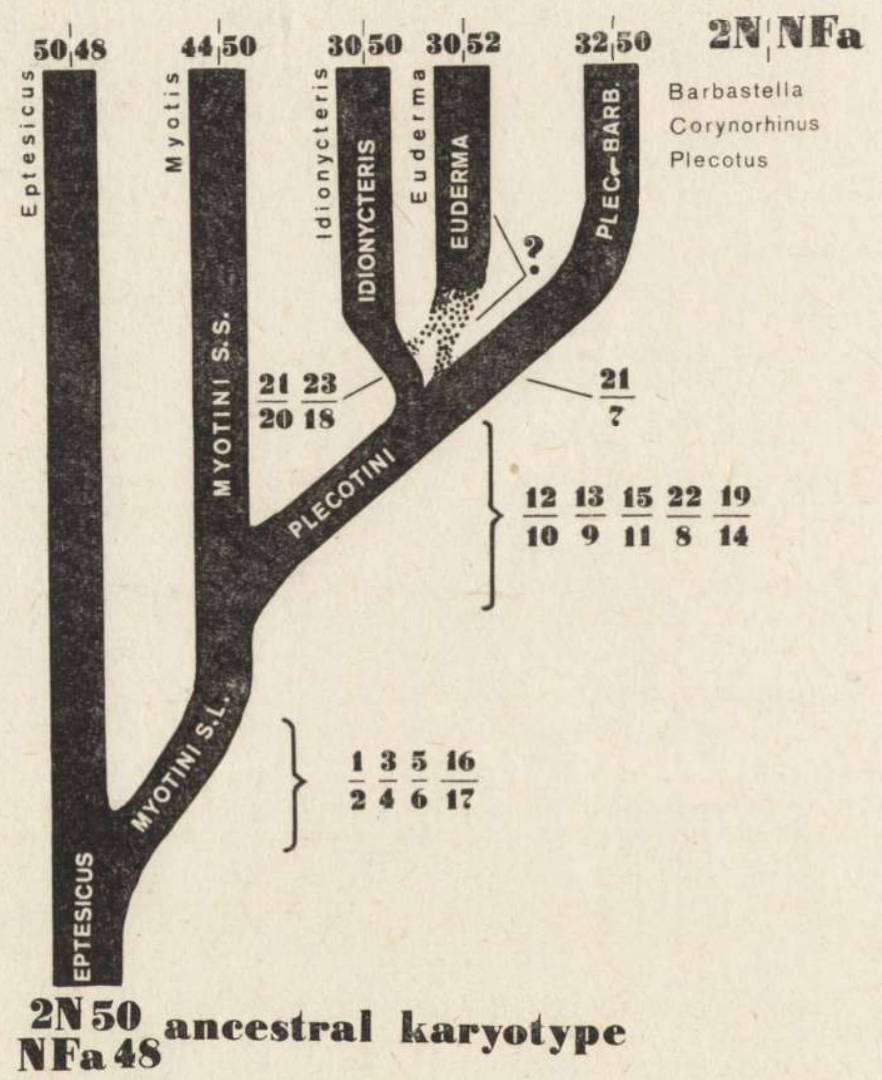

Eig. 1. Hypothetical differentiation of evolutionary lineages of Plecotini karyotypes. White letters denote 7 stages (evolutionary lines) of the karyotype; fractions represent arm combinations evolving in particular lineages.

Among Vespertilionidae, the most primitive karyotype was recorded in species of the genus Eptesicus. This karyotype can be considered as ancestral for all the Vespertilionidae. With respect to morphological characters, however, the genus Eptesicus underwent deep transformation. On the other hand, in the traditional systematics, based on morphology (the dental pattern being, among other features, of great importance for bats), the genus Myotis is considered as very conservative, having 
many ancestral characters of Vespertilionidae. As to the chromosomes, the modern Myotis are at a fairly early stage of evolution (three centric fusions giving rise to pairs $1 / 2,3 / 4,5 / 6$, and an inversion giving rise to an autosome pair 16/17). The occurrence of the same four metacentric autosome pairs in the genera Plecotus and Barbastella suggests that the group Myotini s. $l$. (according to Tate, 1942) branched from common ancestors with chromosomes of the Eptesicus type, the ancestors of Myotini s. s. and Plecotini then forming a common group until the karyotype of the modern Myotis emerged. Only after the formation of the four pairs of metacentric autosomes mentioned above did Pleco.tini separate from Myotini (Fig. 1).

Table 2

Arm composition in big-eared bats. The arms are numbered according to the system used for American forms (Bickham, 1979a) and E. serotinus (Fedyk \& Ruprecht, 1983)

\begin{tabular}{|c|c|c|c|}
\hline & Arm composition of autosomes & & $\begin{array}{l}\text { Morphology of } \\
\text { X-chromosome; } \\
\text { References }\end{array}$ \\
\hline $1 / 2,3 / 4,5 / 6$ & $\begin{array}{c}\text { Plecotus (Idionycteris) phyllotis } \\
16 / 17 \quad 12 / 10,13 / 9,15 / 11,22 / 8,19 / 14\end{array}$ & $23 / 18,21 / 20$ & $\begin{array}{c}\text { sm; } \\
\text { Bickham, } 1979 a\end{array}$ \\
\hline $1 / 2,3 / 4,5 / 6$ & $\begin{array}{l}\text { Barbastella barbastellus } \\
16 / 17 \quad 12 / 10,13 / 9,15 / 11,22 / 8,19 / 14 \\
\text { Plecotus (Corynorhinus) townsendii }\end{array}$ & $21 / 7$ & ${ }_{\text {This paper }}^{\mathrm{sm}}$ \\
\hline $1 / 2,3 / 4,5 / 6$ & $\begin{array}{l}\text { Plecotus (Corynorhinus) townsendii } \\
16 / 1712 / 10,13 / 9,15 / 11,22 / 8,19 / 14\end{array}$ & $21 / 7$ & $\begin{array}{l}\text { Anthony \& Kitchin, } \\
\text { 1976; Bickham, 1979a }\end{array}$ \\
\hline $1 / 2,3 / 4,5 / 6$, & $\begin{array}{c}\text { Plecotus auritus } \\
16 / 17 \quad 12 / 10,13 / 9,15 / 11,22 / 8,19 / 14\end{array}$ & $21 / 7$ & This paper \\
\hline
\end{tabular}

\begin{tabular}{ll} 
Myotis stage & \\
Hypothetical form of ancestral Plecotini & $\begin{array}{l}\text { Plecotini } \\
\text { differentiation }\end{array}$ \\
\cline { 2 - 3 } & Specific for Plecotini only
\end{tabular}

The next five pairs of metacentric autosomes (12/10, 13/9, 15/11, $22 / 8$, and 19/14) are typical only for Plecotini (Bickham, 1979a). These nine pairs of metacentric autosomes are wholly homologous in Plecotus, Corynorhinus, Idionycteris, and Barbastella (Table 2) and therefore must have developed before the big-eared bats split up into Eurasian and Nearctic forms, as well as before the splitting up of Nearctic forms into Idionycteris and Corynorhinus. The occurrence of such a hypothetical karyotype, composed of nine metacentric autosomes, was theoretically suggested even before the first study on the banding pattern in Plecotini had been carried out (Fedyk \& Fedyk, 1971). Further differentiation into two karyotypically different groups was due to various 
combinations of fusions. One group is represented by forms in which a fusion occurred between chromosomes 7 and 21. This lineage then gave rise to the Eurasian species Barbastella and Plecotus and Nearctic species of the subgenus Corynorhinus. In the other group, two centric fusions occurred. Probably the fusion between chromosomes 21 and 20 (instead of chromosome 7) gave rise to the isolation of later Idionycteris from the preceding group. The second fusion occurred between chromosomes 23 and 18. Further differentiation of the chromosome pattern concerned the $X$-chromosome. As Bickham (1979a) has suggested, the acrocentric $\mathrm{X}$-chromosome in Corynorhinus was formed as a result of a pericentric inversion. It is possible that this aberration effectively isolated the ancestors of the present Corynorhinus from the stock that gave rise to the modern Eurasian forms Plecotus and Barbastella. Thus it must have occurred before Plecotini spræad over Asia. Great morphological differences, which resulted in the differentiation of the genera Plecotus and Barbastella, must have been developed relatively recently, after the ultimate termination of the evolution of the chromosome pattern. Karyological data support the suggestion made by Handley (1959) that the majority of cranial characters common to Barbastella, Plecotus, and Corynorhinus, had been evolved before the auditory specialization of the last two genera. Hence, the high degree of specialization of the auricle and auditory capsules in Plecotini is a relatively recent evolutionary acquisition.

As there are no data on banding patterns in Euderma, it is difficult to decide when this genus arose from the common Plecotini ancestors (Fig. 1). It should be emphasized that the term Myotini $s$. $l$. introduced by Tate (1942) on the basis of morphological analysis is very useful here, since it characterizes a certain degree of karyotype evolution, i.e., the development of the karyotype of modern species of the genus Myotis. It should be concluded that all Vespertilionidae species in which there are four pairs of autosomes with arm combinations $1 / 2,3 / 4,5 / 6$, and 16/17 (cf. Bickham, 1979a, b), independent of fusion or other transformations of autosomes $7-15$ and 18-25, must have passed through the chromosome stage of Myotini s. $l$. Thus they must have been a common evolutionary group. In the present study, the term Plecotini is considered as an evolutionary lineage branching from Myotini s. $l$. (the second group consisting of Myotini s. s.). For a long time Plecotini must have formed one Mendelian population until five successive fusions had occurred in it. Consequently, this term denotes here the next stage in the evolution of the chromosome pattern (Plecotini stage). Such an interpretation does not exclude the use of the term Plecotini in the sense of a taxonomic unit involving the modern forms of Euderma, 
Barbastella, Corynorhinus, Idionycteris, and Plecotus. On the other hand, Myotini s. s. is to be considered a modern species of the genus Myotis. Karyologically these are forms with completed karyotype evolution after the pairs $1 / 2,3 / 4,5 / 6$, and $16 / 17$ had been formed (if we ignore some small transformations of the karyotype, cf. e.g. Harada, 1973).

Capanna \& Civitelli (1970) discussed the direction of Robertsonian processes in Vespertilionidae. They stated that the genus Myotis, with the most primitive dental pattern, should be considered as the most primitive also with respect to karyotype. According to these authors (Capanna \& Civitelli, 1970) this ancestral karyotype, made up of four pairs of metacentric autosomes, evolved in two directions: some species (e.g. of the genus Eptesicus) by fissions, while in the other group centric fusions occurred. This reasoning was based on the assumption that all characters evolve in a coordinated way, i.e., if Myotis is conservative in its anatomical characters, then its chromosome pattern must be conservative too. This simplified view is also supported by Baker (1970) and Bickham (1979a), who assume that the modern Myotis have an ancestral karyotype, though Bickham (1979a) agrees that "In general, it would appear that the acrocentric condition is primitive due to the remarkably high frequency of situations in which centric fusions are indicated. Because of this, it is attractive to consider the karyotype of Eptesicus as ancestral...". However, he rejects this concept because of the advanced evolution of morphological characters in Eptesicus.

Certainly, it cannot be stated unequivocally that the ancestral form of Vespertilionidae did not possess the karyotype of the modern Myotis. However, in spite of speculations no evidence has so far been found for the occurrence of centric fissions in Vespertilionidae. It is much more probable that the chromosome pattern evolved owing to centric fusions and, in some rare cases, as a result of inversions and tandem fusions (a complete documentation of the present state of knowledge is given by Bickham, 1979a). It is postulated that the ancestral karyotype of Vespertilionidae consisted of 50 telocentric chromosomes $(2 \mathrm{~N}=50$; $\mathrm{NFa}=48$ ) and thus was identical with the karyotype of modern Eptesicus.

Obviously, the statement that the modern Eptesicus with highly specialized morphological characters are ancestors of Vespertilionidae would be a misunderstanding. Similarly, the modern Myotis, morphologically most conservative, cannot be considered their ancestors either. It should be emphasized that the chromosome pattern is a morphological character equivalent to other characters, e.g. dental characteristics. Moreover, it should not be expected that any animal group includes species with all morphological characters specialized in the same degree, 
while all the characters of other species remained primitive. It should be remembered that an asynchronous evolving of particular characters is in the very nature of evolution.

It has frequently been argued that the chromosome pattern of Eptesicus cannot be ancestral because paleontologically this is a relatively young genus. This argument can easily be rejected in the light of what has been said above; namely, in order to consider the karyotype of Eptesicus as ancestral, it is not necessary to consider the other morphological characters of Eptesicus as ancestral. Simply, it should be stated that the most remote ancestors of Vespertilionidae had a chromosome pattern of $2 \mathrm{~N}=50, \mathrm{NFa}=48$, and cranial characters, mostly teeth, similar to those in modern Myotis. Thus, in this case the absence of Eptesicus fossils in earlier geological strata cannot be used as an argument against a hypothetical ancestral karyotype.

Acknowledgements: The authors would like to thank J. Wójcik, M. Sc. for capturing one specimen of $B$. barbastellus, and Professor A. Krzanowski for making the literature available. Grateful acknowledgement is made to I. Michalak, M. Sc. for critical comments on the first draft of the manuscript and for assistance with the laboratory work, as well as to $\mathrm{H}$. Bajko for technical help.

\section{REFERENCES}

1. Ando K., Tagawa T. \& Uchida T. A., 1977: Considerations of karyotypic evolution within Vespertilionidae. Experientia, 33: 877-879.

2. Anthony M. C. \& Kitchin R. M., 1976. Sex chromosomes and Giemsa banding pattern of Plecotus townsendii. J. Mammal., 57: 165-166.

3. Baker R. J., 1970: Karyotypic trends in bats. [In: "Biology of bats", W. A. Wimsatt ed., Academic Press, N. Y., 65-96].

4. Baker R. J. \& Patton J. L., 1967: Karyotypes and karyotypic variation of North American vespertilionid bats. J. Mammal., 48: 270-286.

5. Baker R. J. \& Mascarello J. T., 1969: Chromosomes of some vespertilionid bats of the genera Lasiurus and Plecotus. Southwest. Naturalist, 14: 249-251.

6. Baker R. J., Davis B. L., Jordan R. G. \& Binous A., 1974: Karyotypic and morphometric studies of Tunisian mammals: bats. Mammalia, 38: 696-710.

7. Bickham J. W., 1979a: Chromosomal variation and evolutionary relationships of vespertilionid bats. J. Mammal., 60: 350-363.

8. Bickham J. W., 1979b: Banded karyotypes of 11 species of American bats (genus Myotis). Cytologia, 44: 789-797.

9. Bovey R., 1949: Les chromosomes des chiroptères et des insectivores. Rev. suisse Zool., 56: $371-460$.

10. Capanna E., Conti L. \& Renzis de G., 1968: I cromosomi di Barbastella barbastellus (Mammalia-Chiroptera). Caryologia, 21: 137-145.

11. Capanna E. \& Civitelli M. V., 1970: Chromosomal mechanisms in the evolution of chiropteran karyotype. Chromosomal tables of Chiroptera. Caryologia, 23: 79-111.

12. Fedyk A. \& Fedyk S., 1970: Karyotypes of some species of vespertilionid bats from Poland. Acta theriol., 15: 295-302. 
13. Fedyk S. \& Fedyk A., 1971: Karyological analysis of representatives of the genus Plecotus Geoffroy, 1818, (Mammalia: Chiroptera). Caryologia, 24: 483-492 .

14. Fedyk S. \& Ruprecht A. L., 1983: Chromosomes of some species of vespertilionid bats. I. Banding patterns of Eptesicus serotinus chromosomes. Acta theriol., 28: $159-170$.

15. Handley C. O., jr., 1959: A revision of American bats of the genera Euderma and Plecotus. Proc. U.S. Nat. Mus., 110: 95-246.

16. Harada M., 1973: Chromosomes of nine chiropteran species in Japan (Chiroptera) La Kromosomo, 91: 2885-2895.

17. Miller G. S., jr., 1907: The families and genera of bats. Washington Government Printing Office, Smithsonian Institution U.S. Nat. Mus. Bull., 57: XI+282.

18. Seabright M., 1971: A rapid banding technique for human chromosomes. Lancet, 2: $971-972$.

19. Tate G. H. H., 1942: Results of the Archbold expedition No 47. Review of the vespertilionine bats, with special attention to genera and species of the Archbold collection. Bull. Amer. Mus. Nat. Hist., 80: 221-297.

20. Tsuchiya K., 1979: A contribution to the chromosome study in Japanese mammals. Proc. Japan Acad., ser. B, 55: 191-195.

21. Uchida T. A. \& Ando K., 1972: Karyotype analysis in Chiroptera. 1. Karyotype of the eastern barbastelle, Barbastella leucomelas darjelingensis and comments on its phylogenetic position. Sci. Bull. Fac. Agric. Kyushu Univ., 26: $393-398$.

22. Williams D. F., Druecker J. D. \& Black H. L., 1970: The karyotype of Euderma maculatum and comments on the evolution of the plecotine bats. J. Mammal., 51: $602-606$.

23. Zima J., 1978: Chromosome characteristics of Vespertilionidae from Czechoslovakia. Acta Sc. Nat. Brno, 12: 1-38.

Accepted, September 15, 1982

Stanislaw FEDYK i Andrzej L. RUPRECHT

CHROMOSOMY KILKU GATUNKOW MROCZKOWATYCH. II. EWOLUCYJNE ZALEŻNOSCI W OBRĘBIE PLECOTINI

\section{Streszczenie}

Zbadano morfologię kariotypów samców gacka wielkoucha, Plecotus auritus (Linnaeus, 1758) i mopka, Barbastella barbastellus (Schreber, 1774) z terenu Polski, przy zastosowaniu barwienia różnicującego (wzór prążków). Wykazano, że kariotypy obu gauntków są identyczne i składają się z 32 chromosomów; 10 par dwuramiennych i 5 par jednoramiennych autosomów, X - submetacentryczny a $\mathrm{Y}$ - mały akrocentryk (Tablica VIII). Barwienia różnicujące pozwoliły stwierdzić całkowitą zgodność wzoru prążków wszystkich chromosomów P. auritus i B. bar- 
bastelíus. Wzory prążków porównywano ze wzorem prążków na jednoramiennych chromosomach mroczka późnego, Eptesicus serotinus (Schreber, 1774), stosując numerację od $1-25$ ramion chromosomów wprowadzoną dla gatunków nearktycznych. Kombinacja ramion autosomów dwuramiennych $P$. auritus i $B$. barbastellus jest następująca: $1 / 2,3 / 4,5 / 6,12 / 10,13 / 9,15 / 11,22 / 8,21 / 7,19 / 14$ i 16/17. Jednoramienne autosomy są porównywalne $\mathrm{z}$ odpowiednimi autosomami Eptesicus i mają następującą numerację: $18,20,23,24$ i 25 . Chromosomy X i Y pozbawione są wy. raźnych prążków (Tablica IX). W oparciu o dane własne i pochodzące z literatury, porównano kariotypy $P$. auritus i $B$. barbastellus na tle kariotypu wyjściowego dla Vespertilionidae (analogiczny $\mathrm{z}$ kariotypem Eptesicus) oraz przedstawicieli Myotini i Plecotini. Omówiono przypuszczalne mechanizmy powstawania kariotypów tych form (Ryc. 1) oraz zestawiono porównanie kariotypów omawianych gatunków (Tabela 1 i 2 ).

EXPLANATION OF PLATES VIII-IX

Plate VIII

Chromosomes of $P$. auritus and B. barbastellus conventionally stained.

Plate IX

Chromosomes of $P$. auritus and B. barbastellus.

In each pair there is a chromosome of $P$. auritus to the left $(\mathrm{P})$ and $B$, barbastellus to the right (B). 


\section{P.auritus}

$3 \times 18$ 118 118

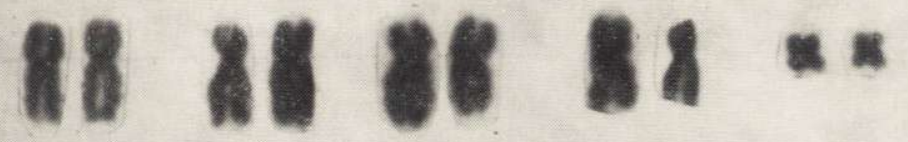

- $\circ+\infty \ldots+1$.

\section{B. barbastellus}

881818 18 8187

की

$A$ ค ค - * B. 

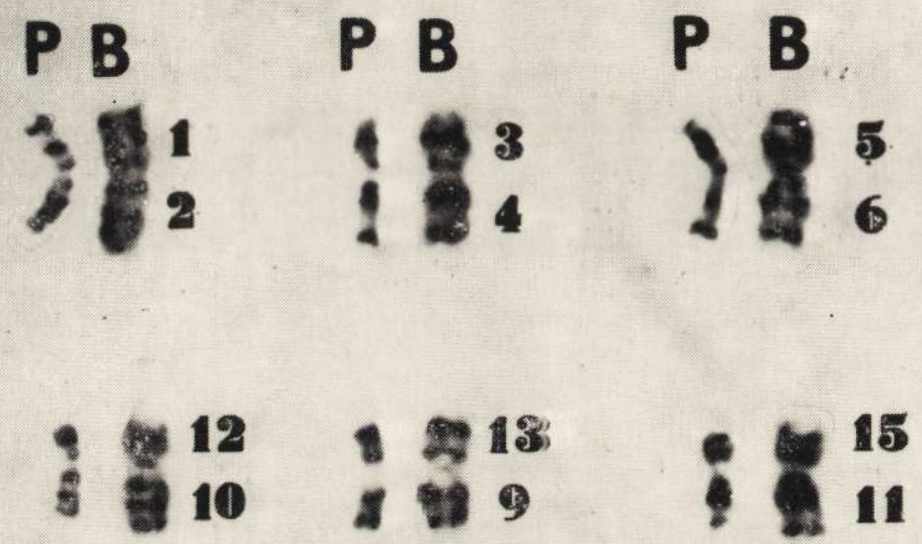

$\because 4 \begin{array}{cc}22 \\ 8\end{array}$

418

$\ldots 20 \quad i=23$

$-24 \cdot-25:-Y 28^{X}$ 